\title{
The Mediating Role of Impulsive Buying in The Relationship Between Fear of COVID-19 and Compulsive Buying: A Research on Consumers in Turkey
}

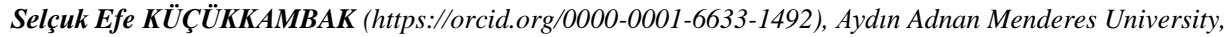
Turkey; efe.kucukkambak@gmail.com

Melek SÜLER (https://orcid.org/0000-0001-8962-9013), Sakarya University, Turkey; meleksuler@gmail.com

\section{COVID-19 Korkusu İle Kompulsif Satın Alma Arasındaki İlişskide İmpulsif Satın Almanın Aracı Rolü: Türkiye’deki Tüketiciler Üzerinde Bir Araştırma}

\begin{abstract}
This study aims to reveal the mediating effect of impulsive buying behaviour in the relationship between fear of COVID-19 and compulsive buying behaviour. In this direction, the data collected from 721 participants by online survey method were analysed using various statistical methods. According to the findings, the fear of COVID-19 experienced by individuals affects compulsive and impulsive buying behaviours. In addition, the mediator effect of impulsive buying behaviour was found in the impact of fear of COVID-19 on compulsive buying behaviour. It is expected that the research results will contribute to the literature in terms of revealing the effect of negative emotional states on consumer purchasing behaviour.

Keywords

: $\quad$ Fear of COVID-19, Compulsive Buying, Impulsive Buying, Consumer Behaviour, Consumer Psychology.

JEL Classification Codes : $\quad$ M30, M31, M39.

\section{$\ddot{\mathbf{O z}}$}

Bu çalışmanın amacı COVID-19 korkusu ile kompulsif satın alma davranışı arasındaki ilişkide impulsif satın alma davranışının aracılık etkisini ortaya koymaktır. Bu doğrultuda 721 katılımcıdan online anket yöntemi ile toplanan veriler çeşitli istatistiksel yöntemler kullanılarak analiz edilmiştir. Elde edilen bulgulara göre bireylerin yaşadıkları COVID-19 korkusu, kompulsif ve impulsif satın alma davranışlarını etkilemektedir. Bunun yanında COVID-19 kaygısının kompulsif satın alma davranışına olan etkisinde impulsif satın alma davranışının mediatör etkisi bulunmuştur. Araştırma sonuçlarının olumsuz duygu durumların tüketici satın alma davranışlarına olan etkisinin ortaya konması bakımından yazına katkı sağlaması beklenmektedir.
\end{abstract}

Anahtar Sözcükler $\quad$ : COVID-19 Korkusu, Kompulsif Satın Alma, İmpulsif Satın Alma, Tüketici Davranışları, Tüketici Psikolojisi. 
Küçükkambak, S.E. \& M. Süler (2022), “The Mediating Role of Impulsive Buying in The Relationship Between Fear of COVID-19 and Compulsive Buying: A Research on Consumers in Turkey", Sosyoekonomi, 30(51), 165-197.

\section{Introduction}

The coronavirus, which emerged in Wuhan, China, in December 2019 and spread throughout the world, has deeply affected the world and humanity in economic, social and many other aspects after being declared a pandemic by the World Health Organization. While it remains unclear how long the pandemic will last, it has become important to reveal how consumers are affected by this process, test the validity of past findings, reveal the reasons behind current behavioural differences and consumption patterns, and make predictions for the future. It is a matter of curiosity to determine the underlying causes of these behaviours of consumers who have been observed to make unplanned purchases during the Covid-19 process (Xiao et al., 2020) and how they will continue in the future. Studies reveal that fear of covid-19 affects consumers' impulsive shopping (Roy \& Chakraborty, 2020). While one of the frequently observed unplanned and impulsive purchases during the pandemic process is impulsive buying behaviour, the other is compulsive buying behaviour (Lopes et al., 2020; Xiao et al., 2020). According to Sulaiman et al. (2020), compulsive buying behaviour that increases in emergencies such as the virus epidemic falls outside the existing theories that explain consumers' normal time buying behaviour.

After being included in psychology books for the first time at the beginning of the 20th century, compulsive buying behaviour, which is one of the unexpected buying behaviours that researchers did not attach importance to for many years, came to the fore again in the late $80 \mathrm{~s}$, this time in the field of consumer behaviour, and many studies have been carried out in the last 20 years. Although there are different results regarding the incidence in society, it is seen that compulsive buyers have increased, especially in the young adult population in developed or developing countries in the last 20 years. Compulsive buying, which is frequently associated with chronic depression (Christenson, 1994), impulse disorder (McElroy et al., 1994), obsessive-compulsive disorder (Lejoyeux et al., 2005), and mood disorder (Müller et al., 2015) buying behaviour is sometimes confused with impulsive buying (Johnson \& Attmann, 2009).

However, there are significant differences between the two concepts in impulsive buying behaviour; the individual buys a certain product with a sudden, impulsive, uncontrollable desire and impulse triggered by an external stimulus (Rook, 1987). It has been found that researchers agree that individuals experience a momentary loss of impulse control in impulsive purchases. It is thought that individuals who make frequent impulse purchases experience more frequent loss of impulse control, which becomes chronic over time, leading to impulse control disorder (Rook, 1987; Hoch \& Loewenstein, 1991). The similarity between compulsive and impulsive buying caused by impulse control disorder has attracted the attention of some researchers. They have determined that individuals' impulsivity, frequently repetitive unplanned and impulse purchases, and purchasing behaviours that are not on shopping lists lead to compulsive buying behaviours over time (Puri, 1996; DeSarbo \& Edwards, 1996; Lejoyeux et al., 1996; Shoham \& Brencic, 2003; Sun et al., 2004 Lejoyeux \& Weinstein, 2010). Behavioural therapy research also 
Küçükkambak, S.E. \& M. Süler (2022), “The Mediating Role of Impulsive Buying in The Relationship Between Fear of COVID-19 and Compulsive Buying: A Research on Consumers in Turkey”, Sosyoekonomi, 30(51), 165-197.

emphasizes that impulsive buying behaviour is a part of compulsive buying behaviour (Müeller et al., 2015).

Very few studies reveal the impact of extraordinary negativities such as epidemics, wars, and natural disasters, which affect humanity on a global scale, on impulsive buying, of which many antecedents have been identified (Sneath et al., 2009). In addition, although compulsive purchases are observed in individuals with anxiety disorders, studies on which types of anxiety affect individuals and how much have not been discussed in detail by researchers until now. Moreover, research on impulsive and compulsive buying has examined different variables that may affect these behaviours and the situations that arise as a result of purchases; it did not consider the hierarchical structure between these two purchasing behaviours together with current variables.

This study examined the effects of negative emotional states such as fear and anxiety, caused by an epidemic that affects all societies globally, on impulsive and compulsive buying behaviours. In this context, in line with the views of researchers who associate impulsive buying behaviour with the impulsiveness of individuals and state that this behaviour can lead to compulsive buying behaviour over time; it is thought that individuals may show compulsive buying behaviour in the face of different anxieties and fears caused by COVID-19, and impulsive buying behaviour has a mediating role in this interaction. This study aims to determine the mediator role of impulsive buying behaviour in the effect of anxiety caused by COVID-19 on compulsive buying behaviours in individuals. This is because it reveals how the impulsive buying behaviour, which is generally associated with positive emotions, is affected by negative emotions, emphasizes the effect of specific anxiety types on impulsive and compulsive buying behaviour instead of a general anxiety state, and considers the hierarchical structure between impulsive and compulsive buying behaviour together with a current variable, this research is expected to contribute to the literature. Moreover, one of the two most researched variables in the literature regarding consumers' impulsive and compulsive buying behaviours is the shopping environment. At the same time, the other is the gender of the individuals who make the purchase. For this reason, the possible differences of the conceptual model determined within the scope of the current research, according to the gender of the participants and the environment in which the participants' shop, will be examined.

The study consists of four parts. Following the introduction, the effects of COVID19 on consumer purchasing behaviour were emphasized with examples from recent studies, and the conceptual framework for impulsive and compulsive buying behaviours was determined. Afterwards, the method section and the results of the field research were included. The findings obtained in the study were compared with the previous analysis. Some theoretical and practical inferences were made, and suggestions were made for similar research to be carried out in the future. 
Küçükkambak, S.E. \& M. Süler (2022), “The Mediating Role of Impulsive Buying in The Relationship Between Fear of COVID-19 and Compulsive Buying: A Research on Consumers in Turkey", Sosyoekonomi, 30(51), 165-197.

\section{COVID-19 Pandemic Period and Its Socio-economic Effects}

The coronavirus pandemic is one of the events that deeply affected countries and citizens of the world in the first quarter of the $21^{\text {st }}$ century, socially, psychologically, economically, and socially. Curfews, social isolation practices, travel restrictions, and many other measures have affected the daily lives of individuals. Fear of catching the disease and death, fear of losing their relatives due to this disease, and the fear of famine have led to various concerns in individuals (Arpac1 et al., 2020; Salari et al., 2020). These anxieties and fears affect many behaviours and consumers' purchasing behaviours (Khan et al., 2021). Although there is much evidence in the literature that individuals triggered by anxiety and fear make impulsive purchases, which purchases increase according to anxiety type is a detailed researcher have relatively ignored. Gallagher et al. (2017) found that physical and cognitive concerns trigger compulsive buying, but social anxiety does not affect consumer buying behaviour. It has been determined that the health anxiety experienced by individuals affects their obsessive-compulsive disorders (Murphy et al., 2010; Brand et al., 2013). It is known that compulsive buying behaviour, which is considered an obsessive-compulsive disorder, also causes compulsive buying in social isolation, loneliness, and alienation resulting from social dynamics (Valence et al., 1988; O'Guinn \& Faber, 1989). So, did the isolation of individuals, social isolation, and various fears due to the COVID-19 process affect compulsive buying behaviours?

Lopes et al. (2020) found that fear of COVID-19 explains a significant part of the variance towards compulsive buying behaviour. During the pandemic process, the number of shopping made in the store environment is decreasing (Grashuis et al., 2020); even consumers who do not usually prefer online shopping have started to shop online during the pandemic period (Watanabe \& Omori, 2020). Another consumption habit change caused by the fear of coronavirus is the stocking behaviour (Sheth, 2020) caused by the fear of scarcity (Hamilton, 2021; Jezewska-Zychowicz et al., 2020). This behaviour is associated with individuals' fast and emotion-oriented thinking (Melo, 2020). Islam et al. (2020) found that the fear of scarcity caused by COVID-19 increased impulsivity and significantly affected impulsive and compulsive buying behaviours. In response to the uncertainty they experienced during the pandemic, individuals preferred to stock up by purchasing toilet paper, durable food and cleaning materials, and medical supplies, which they saw as basic needs (Terlep, 2020; Dietrich et al., 2020). For example, Chenarides et al. (2021), in their study conducted in May-2020, when the first severe effects of the coronavirus were seen in the United States, found that many consumers shopped at the grocery store excessively compared to their regular purchases due to the fear of product stocks being left. They were hesitant to make these purchases in the store environment. Schiller et al. (2021) consider this type of significant stocking behaviour during the pandemic period as an obsessivecompulsive tendency. The stocking behaviour of the individual is seen as a way of coping with the stress of life-threatening situations, suppressing or overcoming anxiety (Krafft et al., 2020). Chen et al. (2017) explained such behaviours of consumers in the context of Compensatory Control Theory and stated that uncertainty, anxiety, fear from the pandemic caused control weakness. Çelik and Köse (2021), on the other hand, found that increased 
Küçükkambak, S.E. \& M. Süler (2022), “The Mediating Role of Impulsive Buying in The Relationship Between Fear of COVID-19 and Compulsive Buying: A Research on Consumers in Turkey”, Sosyoekonomi, 30(51), 165-197.

anxiety and stress in Turkish consumers with COVID-19 increased compulsive buying and stocking. Xiao et al. (2020) found that COVID-19 pressure increases perceived uncertainty, which increases individuals' daily arousal levels, and this increase in arousal increases impulsive buying.

One of the most important reasons that cause such shopping is anxiety disorder (Petersen, 2020), mood disorder, excessive internet use, and extreme loneliness and depression due to social isolation (Donthu \& Gustafsson, 2020). Li et al. (2020) stated that individuals, being stimulated due to negative emotions such as fear, perform panic buying behaviour, which is a kind of impulsive buying behaviour common in consumers during crisis periods (Roy \& Chakraborty, 2021). Nakano et al. (2020) found that those who made more panic purchases during the pandemic were prominent family members, were generally male, and prone to impulsive purchases. Lovato et al. (2020) found that unusual purchases were associated with voluntary social isolation behaviours during the COVID-19 process. It is necessary to clarify how much the fear of COVID-19 and the impulsive shopping behaviour applied to calm down the negative emotions caused by this fear affect the society in emergencies and crisis processes, at what level, and whether it continues in the future (Billore \& Anisimova, 2021). Taylor et al. (2020) also stated that more studies are needed in this area to determine the persistence of stress-induced behavioural changes caused by COVID-19.

Although it is known that impulsive buying, which depends on the emotional state of individuals, usually occurs after positive emotional states (Rook \& Gardner, 1993), studies revealing the effect of negative emotions are very few. Shahjehan et al. (2012) expressed this situation as "definition myopia". This study examined the impact of various fears experienced by individuals as a negative factor causing impulsive buying behaviour. The hypotheses are determined in this direction.

H1: Psychological fear directly affects impulse buying.

H2: Psychosomatic fear directly affects impulse buying.

H3: Social fear directly affects impulse buying.

H4: Economic fear directly affects impulse buying.

\section{Compulsive Buying}

\subsection{Theoretical Background and Definitions}

Compulsive purchasing is an internal (rarely external) and overbearing behaviour with an overwhelming purchase impulse (O'Guinn \& Faber, 1989). Some researchers replace the expression of compulsive buying with shopping addiction (Glatt \& Cook, 1987; Schernorn et al., 1990), shopping spree (Winestine, 1985; Koran, 1999), consumption disorder (Faber et al., 1995), compulsive consumption. (Faber et al., 1987), consumption addiction (Hirschman, 1992), spending addiction (Hanley \& Wilhelm, 1992; Campbell, 2000). Unlike regular purchases, compulsive buying behaviour, characterized by excessiveness, frequent repetition, and causing negative situations, is a particular form of 
Küçükkambak, S.E. \& M. Süler (2022), "The Mediating Role of Impulsive Buying in The Relationship Between Fear of COVID-19 and Compulsive Buying: A Research on Consumers in Turkey”, Sosyoekonomi, 30(51), 165-197.

compulsive consumption. The differences between the two concepts are explained in consumption and addiction O'Guinn and Faber (1989). Consumption of any substance includes experiences such as time, space, and the benefit obtained from its use (Schmit, 1999). However, in compulsive purchasing, it is the act of shopping that matters rather than the experience or benefit of using the purchased product (Lejoyeux et al., 1996). This feature indicates that compulsive buying is a kind of addiction (Lejoyeux \& Weinstein, 2010). However, shopping is an act to escape from negativities such as tension, anxiety, anger, not the product. Addictions such as alcohol, cigarettes, drugs, overeating, and sex cause physiological harm to the individual. However, few of the damages caused by shopping addiction are stress-related, so they are considered physiologically (O'Guinn \& Faber, 1989). The harms that occur in compulsive shopping are in the form of insolvency, regret, tensions in family or friends (Goldsmith \& McElroy, 2000). In addition, while the interest in the product continues in substance addiction, after the compulsive shopping, the interest in the product ends (O’Guinn \& Faber, 1989).

Before compulsive buying behaviour, the individual is strongly triggered by an internal stimulus. Negative moods such as fear, anxiety, boredom, self-critical thinking, and sadness determine the severity of arousal. The only thought of where, when, and how to shop occupies the individual's mind, whose urge to shop in a way that disables the cognitive processes are intensified, and one's willpower weakens. At this stage, the individual's aim is not what the product to buy or how it will benefit, but to get rid of the negative emotional state and tension, even temporarily, by shopping (Dell'Osso et al., 2006). The relief experienced is short-lived, followed by feelings of regret and guilt (Faber \& O'Guinn, 1988; Lee \& Workman, 2018).

Moreover, excessive shopping for this temporary sense of relief can lead to various socio-economic and legal problems and even family conflicts (Christenson et al., 1994; Park \& Burns, 2005; Black, 2007). Despite these negative situations after shopping in compulsive buying behaviour, the individual soon purchases by following the same stages. Although the individual notices the loss of impulse control and the negative situations observed as a result of the behaviour, the compulsive buying behaviour is seen as an addiction due to the repetition of the same behaviour (Valance et al., 1988; DeSarbo \& Edwards, 1996).

\subsection{Compulsive Buyers}

Compulsive buyers generally have low self-esteem (Yurchisin \& Johnson, 2004), high brand attachment (Japutra et al., 2019), materialistic (Dittmar, 2005; Xu, 2008; Mueller et al., 2011), propensity to daydream high (Edwards, 1992), prone to depression (Scherborn et al., 1990; Mueller et al., 2011), low self-esteem (Krueger, 1988; Marlatt et al., 1988), high anxiety level (Schlosser et al., 1994; Black, 2007) are characterized as individuals. In addition, compulsive buyers have more credit cards (Dittmar, 2005), are willing to talk more on mobile phones and connect to online shopping sites frequently (Lejoyeux et al., 2007), and are prone to online shopping due to the ease of access (Wang \& Yang, 2008). Although their shopping frequency varies from once a month to several times a day, they shop 2-3 
Küçükkambak, S.E. \& M. Süler (2022), “The Mediating Role of Impulsive Buying in The Relationship Between Fear of COVID-19 and Compulsive Buying: A Research on Consumers in Turkey”, Sosyoekonomi, 30(51), 165-197.

times a week on average (Christenson et al., 1994; Schlosser et al., 1994). Compulsive buyers, who can't help but think about shopping or spending in their daily lives, care about their appearance (Krueger, 1998), are fond of fashion (Park \& Burns, 2005), and are highly interested in new products (Black, 2007). A significant proportion of compulsive buyers have mood disorders (Lejoyeux et al., 1996), anxiety (Schlosser et al., 1994; Roberts \& Jones, 2001), substance use (Christenson et al., 1994; Black et al.) 1998), eating disorder (Finke \& Huston, 2003; Faber, 2010), internet addiction (Mueller et al., 2011), impulse control disorder (Hanley \& Wilhelm, 1992), obsessive-compulsive disorder (McElroy et al., 1994; Black et al., 1998), excessive stacking (Frost et al., 2002, Lejoyeux \& Weinstein, 2010) have been observed. Schlosser et al. (1994) also observed behaviours such as returning purchases, not taking them out of the package, selling or giving to someone else in compulsive buyers.

Hirschman (1992) categorized compulsive buyers as sociopathic and distressed. For compulsive buyers at the sociopathic level, the act of shopping is a kind of addiction. In contrast, for distressed compulsive buyers, the purchased products are a way of relaxation and stress relief (Neuner et al., 2005). Edwards (1993) categorized compulsive buying behaviour as chronically addicted, compulsive, uncertain, and non-compulsive buying behaviours. Faber and O'Guinn (2008) made a similar distinction, and compulsive buyers were categorized as pathological buyers and excessive buyers. According to the researchers, who suggest measuring both groups with the same scale, more research should be done in the future to distinguish between these two groups of consumers.

DeSarbo and Edwards (1996) suggested examining individuals' purchasing motivations to interpret whether their purchases are excessive or compulsive. While buyers at the pathological level make compulsive purchases chronically and repetitively, unreasonable buyers are not as severe as the other group. Although extreme buyers are similar to pathological buyers in many aspects, they make purchases positively (Beatty \& Ferrel, 1998) and use what they buy (Yurchisin \& Johnson, 2004). While pressure and tension are dominant in pathological buyers when something is not purchased, such a situation is not observed in excessive buyers (Rook \& Gardner, 1993).

According to the researchers who consider compulsive purchasing behaviour an impulse control disorder, the most crucial difference in compulsive purchasing behaviour as in all impulse control disorders is related to gender (Popkin, 1989; McElroy et al., 1991; Christenson et al., 1992). Although studies are showing that men and women make compulsive purchases at similar rates (Koran et al., 2006), the standard view among researchers is that compulsive buyers are generally women (O'Guinn \& Faber, 1989; Roberts, 1998; Yurchisin \&amp; Johnson, 2004; Dittmar, 2005). While women (Schlosser et al., 1994; Black, 2001, 2007) generally make compulsive purchases in clothing, shoes, cosmetics, and jewellery, men (McElroy, 1994) buy automotive and technological products their hardware parts. In addition, it is known that compulsive buyers are generally between the ages of 18-30, when they move away from their nuclear families and step into a free life when they can get a loan for the first time and have their first credit card, and who have not 
Küçükkambak, S.E. \& M. Süler (2022), "The Mediating Role of Impulsive Buying in The Relationship Between Fear of COVID-19 and Compulsive Buying: A Research on Consumers in Turkey”, Sosyoekonomi, 30(51), 165-197.

thought of getting married yet (Black, 2007). Although there is no generalizable relationship between compulsive shopping behaviour and income level (Christenson et al., 1992), pathological compulsive buying behaviour is observed more frequently in low-income individuals (Black, 2001).

Research on consumer buying behaviour has shown that any single factor cannot explain compulsive buying behaviour. Therefore, researchers have adopted the bio-psychosocial model, assuming that all physiological, biological, genetic, psychological, social, and cultural factors cause this behaviour disorder (Faber, 1992). Despite this approach, studies on the details of fears or anxieties that impact individuals' impulsive buying behaviours have remained very limited in previous studies. This study examined the effects of psychological, psychosomatic, social, and economic fears experienced by individuals on compulsive buying behaviour. The hypotheses are determined in this direction.

H5: Psychological fear directly affects compulsive buying.

H6: Psychosomatic fear directly affects compulsive buying.

H7: Social fear directly affects compulsive buying.

H8: Economic fear directly affects compulsive buying.

\section{Impulsive Buying}

\subsection{Theoretical Background}

Impulsive buying behaviour has become a topic of interest to marketing researchers since the early 50s (Clover, 1950). Initially, the common view was that impulsive purchasing was a form of unplanned purchasing behaviour (West, 1951). According to this view, impulsive purchasing was in the form of a positive difference between the shopping list planned before shopping and after the actual purchase (Weinberg \& Gottwald, 1982). This period examined what impulsive purchases were among unplanned purchases in general, not the factors that affected impulsive purchasing behaviour. As consumer-focused approaches in the field of marketing become up-to-date, researchers have associated impulsive purchases with moods and impulsiveness (Lee \& Yi, 2008), and it has been found that this behaviour occurs thoughtlessly, in search of excitement, and as a result of high arousal (Kacen \& Lee, 2002). Researchers have focused mainly on determining the antecedents of impulsive buying behaviour in recent years.

Impulsive buying behaviour is associated with reactive personality traits (Rook, 1987). These people experience tension to get rid of the negativities they encounter quickly. They try to overcome the current negative situation by losing their cognitive control. One of these ways is impulse buying behaviour (Weinberg \& Gottwald, 1982). Impulsive buying is an instantaneous behaviour stimulated by a strong and often irresistible urge, with no consequences, which is likely to cause emotional conflict due to its hedonic complexity (Rook, 1987). In impulsive purchases, the individual does not experience processes such as collecting information about the product, making comparisons, and getting recommendations, and the feeling of relief after the purchase is at the forefront as an 
Küçükkambak, S.E. \& M. Süler (2022), “The Mediating Role of Impulsive Buying in The Relationship Between Fear of COVID-19 and Compulsive Buying: A Research on Consumers in Turkey”, Sosyoekonomi, 30(51), 165-197.

individual makes an instant purchase decision to suppress the impulse (Jones et al., 2003; Verplanken \& Sato, 2011; Jones et al., 2003). After impulsive shopping, some financial problems, mood disorders, weak willpower, guilt, and various social issues may occur (Rook, 1987; Gardner \& Rook, 1988; Kivetz \& Zheng, 2006; Zhang \& Shrum, 2009).

Some factors that affect the impulse buying behaviour of individuals consist of instore variables controlled by marketers such as advertising activities, well-trained salespeople, various sales, and the atmosphere and design of the store consisting of store type, size, lighting, and sound system. (Youn \& Faber, 2000; Karabasivar \& Yarahmadi, 2011; Chang et al., 2011; Mohan et al., 2013; Vishnu \& Raheem, 2013; Sun \& Yazdanifard, 2015). These variables are now expressed as innovative sales, promotions, creative messages, and appropriate technologies (Schiffman \& Kanuk, 2010). In online purchases, these factors include the time spent on the website, the website's ease of use, the page's colouring and design, and the online support services on the page (Ling \& Yazdanifard, 2015). Internal factors that have an impact on impulse purchasing behaviour are different personalities and characteristics (Muruganantham \& Bhakat, 2011; Putra et al., 2017; Sofi \& Nika, 2016; Miao et al., 2019), positive emotions (Chang et al., 2011), individual norms (Rook \& Fisher, 1995), greater feelings of amusement, delight, enthusiasm, joy (Weinberg \& Gottwald, 1982), lifestyle, materialism and sensation seeking (Rook, 1987), a personal tendency to buying impulse (Rook \& Fisher, 1995; Putra et al., 2017), variety seeking (Sharma et al., 2010), lack self-control (Youn \& Faber, 2000), hedonic needs and motivations (Hausman, 2000; Beatty \& Ferrel, 1998; Dey \& Srivastava, 2017). In addition, location, shopping duration, shopping period and shopping habits (Shapiro, 1992; Jeffrey \& Hodge, 2007), functional benefits (Schiffmann \& Kanuk, 2010), product-oriented involvement (Jones et al., 2003; Chen, 2008); Liang, 2012), the attractiveness of product packaging (Hubert et al., 2013), affects spending habits and impulsive buying behaviours (Beatty \& Ferrel, 1998). Sneath et al. (2009) found that stress and depressed mood affect impulsive and compulsive purchasing.

Emphasizing that impulsive buying behaviour is positively affected by changing market dynamism and consumption habits (Hock \& Loewenstein, 1991), impulsive buying tendency (Sun \& Wu, 2011; Foroughi et al., 2013), internet addiction (Sun \& Wu, 2011), increase in income level (Beatty \& Ferrel, 1998), widespread use of the internet and online shopping (Kacen \& Lee, 2002; Sun \& Wu, 2011), rise in technological developments (Lee \& Yi, 2008), cultural effects (Dawson \& Kim, 2009) and various consumption impulses; beside; It has been determined (Rook \& Fisher, 1995), that the norms that characterize the society as risky, immature, wasteful and irrational and task orientation (Sun \& Wu, 2011) negatively affect it. Hausman (2000) emphasized that individuals reporting negative emotions after impulsive purchases are less than expected, and therefore, impulsive buying behaviour is more associated with satisfaction, hedonism, and positive emotional components. 
Küçükkambak, S.E. \& M. Süler (2022), "The Mediating Role of Impulsive Buying in The Relationship Between Fear of COVID-19 and Compulsive Buying: A Research on Consumers in Turkey”, Sosyoekonomi, 30(51), 165-197.

\subsection{Impulsive Buyers}

Impulsive buyers enjoy touching the product before purchasing (Peck \& Childers, 2006), have high brand loyalty (Japutra et al., 2019); generally, women and young (Sharma, 2011) have a strong emotional bond with the product and desire instant satisfaction (Sharma, 2011), have extroverted personalities (Verplanken \& Herabadi, 2001), are materialistic (Troisi et al., 2006), and do not take into account possible post-purchase negativities (Hoch \& Loewenstein, 1991). In addition, these people are highly aroused by external stimuli and immediately respond to impulse buying impulses (Rook \& Fisher, 1995). These individuals, who are interested in the symbolic aspects of products, see shopping as a means of expressing themselves. However, it varies from person to person, and often buy products such as perfumery, cosmetics, clothing, fashion products, and sports products instantly (Dittmar et al., 1995, 1996; Pradhan, 2016). One of the most studied variables in impulsive buying behaviour was gender. Many studies show that positive emotions towards purchasing, irresistible urges towards shopping, and unplanned shopping are more common in women (Coley \& Burgess, 2003). Verplanken and Sato (2011) emphasize that impulsive buyers cannot give up on purchasing despite having economic difficulties because of high impulsiveness. For this reason, individuals with high impulsive buying tendency, when they encounter attractive products, desire to own them even if they do not have enough cash, even by using a credit card. (Roberts \& Jones, 2001; Ramanathan \& Menon, 2006).

Faber (2010) considered impulsive purchasing behaviour as an unexpected and ordinary behaviour that everyone can experience at least once in their life, while compulsive buying is regarded as a psychological disorder that is present in a small number of people and emphasized the negative feelings experienced by the individual as a result. Shoham and Brenic (2003) stressed that the first step of consumers' compulsive purchasing behaviour process is unplanned, instant, sudden, and impulsive purchases made with an impulse from outside. Kwak et al. (2006) emphasized that impulsive and compulsive purchasing behaviour cannot be considered separately because of impulse control disorder or weakness and negative moods, being unplanned, generally making large amounts of purchases from the same products, and negative situations that occur after purchasing are similar. Darrat et al. (2016) emphasized that the tension that will arise after impulsive buying can trigger compulsive buying behaviour. Verplanken and Sato (2011) stressed that impulsive buying could turn into compulsive buying behaviour over time, and in this case, pathological consequences of impulsive buying behaviour may occur. D'Astous (1990) emphasized that if the impulse to buy is persistent and excessive, it can become low-level compulsive buying behaviour.

On the other hand, the mediating role of impulsive buying behaviour, which has been found to mediate compulsive buying behaviour in a limited number of studies, on the effect of fears created by COVID-19 in consumers on compulsive buying behaviour has been examined within the scope of this research. The hypotheses are determined in this direction.

\section{H9: Impulsive buying directly affects compulsive buying.}


H10: Impulsive buying has a mediating effect on COVID-19 fear on compulsive buying.

\section{Methodology}

\subsection{Research Model, Measures and Procedures}

The primary purpose of this research is to examine the relationship between the various fears that individuals experience during the COVID-19 pandemic and compulsive buying behaviours and determine the mediator role of impulsive buying behaviour in this relationship. The research is explanatory. Within the scope of the study, first of all, a detailed literature review was done. In the current studies in the literature, it has been determined that various fears experienced by individuals due to COVID-19 affect their purchasing behaviour. The research has determined that multiple fears caused by COVID-19 mainly focus on compulsive buying, which can be expressed as excessive or obsessive buying behaviour, impulsive buying, which can be defined as impulse buying, and panic buying behaviour. Accordingly, individuals under the influence of negative moods may exhibit compulsive buying behaviour, and impulsive buying behaviour was interpreted as a variable that could mediate this interaction and was included in the research model. The research model and hypotheses specified in Figure 1 were created in this direction.

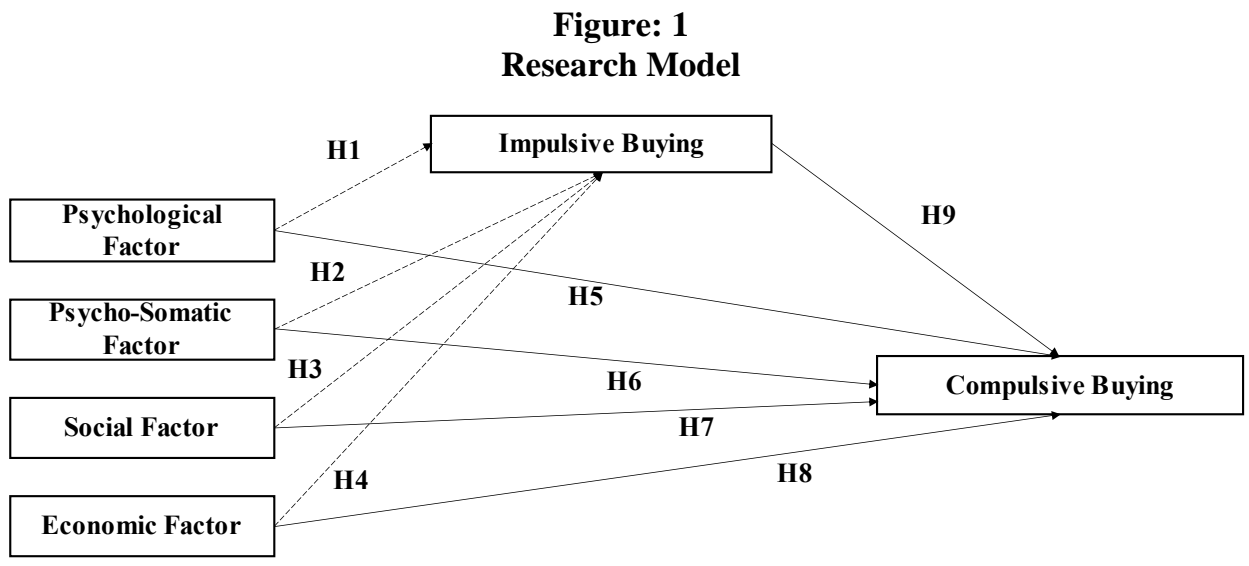

Although there is no clinically definitive diagnostic guide for the detection of compulsive buying behaviour, the most frequently used methods in the field of consumer behaviour and psychiatry are observing the purchasing behaviour of individuals in terms of amount, duration, spending amount, detecting other accompanying mental disorders or using face to face interview technique is to ask questions (Müller et al., 2015).

When the literature is examined, studies investigating the relationship between the purchasing behaviour of individuals and various demographic characteristics, the environment in which they shop, the frequency of shopping, the frequently preferred 
Küçükkambak, S.E. \& M. Süler (2022), "The Mediating Role of Impulsive Buying in The Relationship Between Fear of COVID-19 and Compulsive Buying: A Research on Consumers in Turkey”, Sosyoekonomi, 30(51), 165-197.

payment method, and the product group purchased have been found. On top of that, while the questionnaire was being prepared, online interviews were conducted with 20 participants who participated voluntarily. Questions were asked about the details of their shopping during the pandemic period. The answers obtained were brought together. The questionnaire form included questions to determine the participants' demographic characteristics and shopping habits and the answer alternatives included in these questions. After the questionnaire form was created at the beginning of the study, a pilot study was conducted in which 50 people participated. According to the data obtained from this study, it was observed that the corrected item-total correlation value of 32 items was not found to be below $0.3(0.508$ 0.781 ), and it was decided to apply the questionnaire to the final participants.

\subsection{Participants}

The online survey method was preferred as a data collection technique in the study. Data were collected between 10.05./20.05.2021 after obtaining the approval of the ethics committee. While transferring the questions to the online survey provider, some measures were taken to protect the data quality. Accordingly, rules such as answering only one survey from each electronic device, giving a system warning in case of incomplete answers, and showing the progress on the home page have been set. Due to the global pandemic conditions, the convenience sampling method was applied to make it easier for the participants to reach the survey and increase the number of answers. Accordingly, the access link to the study was systematically shared with 20 people in the close circle of the researchers, and these people were asked to answer the survey first and then share it with 20 people in their process. In addition, the researchers transferred the link to the questionnaire with the people they were in close contact with through their social media accounts, and the same request was made from these people. Since the target population to be studied within the scope of the research is more significant than ten thousand, the sufficient sample size was determined as at least 384 according to the calculation method suggested by Aaker et al. (2013: 382). However, the previously targeted sample size was exceeded to reduce the sampling error during the data collection phase. At the end of the data collection process, it was seen that 721 participants answered the questionnaire thoroughly.

\section{Findings}

\subsection{Demographic Characteristics}

$75.9 \%$ of the participants are women, $65.7 \%$ are married, $20.5 \%$ are between the ages of $18-28,41.2 \%$ are between the ages of $29-39,23.3 \%$ are between the ages of $40-50$ period, $12.5 \%$ are $51-61$ years old, and $2.5 \%$ are 62 years old or over. While $14 \%$ of the participants have a postgraduate education level, 61.6\% are 4-year university graduates, $6.8 \%$ are 2-year university graduates, and $17.6 \%$ have a high school or lower education. In addition, $8.9 \%$ of the participants are students, $46.6 \%$ are civil servants, $15.8 \%$ are private-sector employees, $8.5 \%$ are self-employed, $9.3 \%$ are retired, $9,8 \%$ are unemployed, $1.1 \%$ are housewives. On the other hand, when the monthly incomes of the participants are examined, $23 \%$ of them 
Küçükkambak, S.E. \& M. Süler (2022), “The Mediating Role of Impulsive Buying in The Relationship Between Fear of COVID-19 and Compulsive Buying: A Research on Consumers in Turkey”, Sosyoekonomi, 30(51), 165-197.

are $2.500 \mathrm{TL}$ or less, $34 \%$ of them are between $2,501-5.000 \mathrm{TL}, 30.4 \%$ are between 5.001 - $7.500 \mathrm{TL}, 8.2 \%$ are between 7.501 - 10,000 TL, $4.4 \%$ of them were found to be $10,001 \mathrm{TL}$ or more.

\subsection{Shopping Habits During Pandemic}

When the product groups that the participants spent the most during the pandemic process were examined, it was observed that $72.5 \%$ of the participant spent on food while $10.7 \%$ cleaning, $3.3 \%$ paper and cosmetic products, $2.6 \%$ baby and mother care products, $3.2 \%$ various household product, $1.2 \%$ for electronic products, $2.9 \%$ for books, magazines or stationery products, and $3.5 \%$ for clothing. While $38.8 \%$ of the participants preferred the store environment for their shopping, $61.2 \%$ of them shopped online. $1.5 \%$ of the individuals participating in the study had shopping several times a day during the pandemic process while $8.5 \%$ once every day, $15.4 \%$ once every two days, $31.3 \%$ twice a week, $25 \%, 4$ of them shop once a week, $11.1 \%$ twice a month, and $6.8 \%$ had shopping once a month. $19.4 \%$ of the participants preferred to pay in cash during the pandemic period, while $75.6 \%$ were selected by credit card, $2.6 \%$ by money order-eft, $1.9 \%$ by cash on delivery, and $0.4 \%$ by shopping loans.

\subsection{Validity and Reliability of Measures}

\subsubsection{Fear of COVID-19}

The COVID-19 Phobia Scale developed by Arpac1, Karataş, and Baloğlu (2020) was used to determine the fears of the individuals participating in the study about COVID-19. The original form of the scale is 4-dimensional, consists of a total of 20 items, and is graded with a 5-point Likert scale ( $1=$ Strongly Disagree and 5=Strongly Agree). As a result of the explanatory factor analysis, Arpac1 et al. (2020) observed that the factor loads of the items in the scale were between 0.45 and 0.87 and determined that the Cronbach's alpha coefficient was 0.925 as an internal consistency measure of the scale. Explanatory factor analysis was conducted to determine the factor structure of the measurement scales used to measure the study's participants' fears. While applying the factor analysis, varimax rotation was chosen. Factors with an eigenvalue greater than one were taken into account to determine the optimal number of independent factors (Hair et al., 2014). In the explanatory factor analysis performed with varimax rotation in the current study, it was seen that the scale had four dimensions, and the total explained variance was $68.869 \%$ (KMO: 0.927, Bartlett $\chi 2: 9295,422, p: 0.000)$. The first dimension is named as "Psychological Fear" dimension. It was determined that the psychological fear dimension explained $20.203 \%$ of the total variance, consisting of 6 items $(\overline{\mathrm{X}}=3.88, \sigma=0.91)$, and the factor loadings of the items were between 0.49 and 0.83 . The second dimension was named "Psychosomatic Fear", and it was seen that there were five items $(\overline{\mathrm{X}}=1.83 \sigma=0.89)$ under this dimension, which explained $17.731 \%$ of the total variance, and the factor loadings of the items were between 0.64 and 0.85. The third dimension of the scale was named "Social Fear", and it was seen that this dimension consisted of five items $(\bar{X}=3.11, \sigma=1.11)$, explained $16.631 \%$ of the total variance, 
Küçükkambak, S.E. \& M. Süler (2022), “The Mediating Role of Impulsive Buying in The Relationship Between Fear of COVID-19 and Compulsive Buying: A Research on Consumers in Turkey”, Sosyoekonomi, 30(51), 165-197.

and factor loadings the items ranged between 0.63 and 0.79 . The fourth dimension of the scale was named "Economic Fear", and it was seen that this dimension consisted of four items $(\overline{\mathrm{X}}=2.12, \sigma=0.99)$, explained $14,305 \%$ of the total variance, and the factor loads of the items varied between 0.74 and 0.79 . The Cronbach's alpha value calculated as the internal consistency coefficient of the scale is 0.932 , and this value is 0.89 in the psychological fear dimension, 0.89 in the psychosomatic fear dimension, 0.89 in the social fear dimension, and 0.85 in the economic fear dimension. Since the scale was adapted to a different sample group, confirmatory factor analysis was applied to the obtained data. It was observed that the initial model was not confirmed, and the modifications suggested by the model were performed accordingly $\left(\chi^{2} / d f: 6,071\right.$, GFI:0,870, CFI: 0,910, NFI:0,894, TLI:0,895, RMSEA:0,084). At this stage, after the covariances were drawn between the 1 st and 2 nd items for the economic anxiety of COVID-19 and between the 3rd and 4th items for the social anxiety, the model reached acceptable levels of fit. The compatibility of the collected data with the scale in the literature was verified $\left(\chi^{2} / d f: 3,815, G F I: 0,920, C F I: 0,950\right.$, NFI:0,934, TLI:0,895, RMSEA:0,063). It was found that the standardized factor loads obtained as a result of the analysis were 0.59 to 0.85 ( $\mathrm{AVE}=0.59, \mathrm{CR}=0.90$ ) in the psychological fear dimension, 0.72 and 0.87 (AVE $=0.64, \mathrm{CR}=0.90)$ in the psychosomatic fear dimension, 0.71 to 0.84 ( $\mathrm{AVE}=0.57, \mathrm{CR}=0.87$ ) in the social fear dimension and $0.52-$ 0.88 ( $\mathrm{AVE}=0.56, \mathrm{CR}=0.90$ ) in the economic fear dimension. To determine the construct validity, it was seen that the construct validity of the scale was provided according to the average explained variance (AVE) and composite reliability (CR) values with standardized factor loads obtained by exploratory factor analysis.

\subsubsection{Compulsive Buying Scale}

The Compulsive Buying Scale developed by Faber and O'Guinn (1992) was used to measure the compulsive buying behaviours of individuals in the current study. The original form of the scale consists of a total of 7 items and is graded with a 5-point Likert scale ( $1=$ Strongly Disagree and 5=Strongly Agree). Since the compulsive buying scale was adapted into Turkish with different expressions by many researchers, permission to use the scale was obtained from Thomas O'Guinn before it was used within the scope of the current study. The items were adapted into Turkish by adhering to the literature. Since the scale was developed a long time ago, several procedures were followed to comply with today's conditions and at the same time adhere to the original form. Accordingly, the opinions of English and Turkish language experts were taken for the translated scale items. Then the views of two Turkish researchers working as an academician in the Department of Business Administration in the United States were sought. In line with the suggestions received, the translations were revised. This time, a pre-test was conducted for 20 graduate students with a doctorate or master's degree in business administration and a good command of English or Turkish languages. In addition to the notifications from these individuals, the opinions of 2 different academicians working as an academician in the Department of Business Administration in Turkey and two academicians in the Department of Psychology were taken. 
Küçükkambak, S.E. \& M. Süler (2022), “The Mediating Role of Impulsive Buying in The Relationship Between Fear of COVID-19 and Compulsive Buying: A Research on Consumers in Turkey”, Sosyoekonomi, 30(51), 165-197.

Finally, to prevent the possibility of Turkish expression disorder in expressions, the scale was checked by Turkish language experts. The final form of the compulsive buying scale was given following the use of the current study. According to the explanatory factor analysis applied to the scale, the compulsive buying scale is one-dimensional, and the total explained variance of the scale is 60,334\% (KMO:0,849 Bartlett, $\chi 2: 1270,041, p: 0,000$ ). Since the factor loads of the 6th and 7th items in the ranking were below the values recommended by Tabachnick and Fidell (2013), they were excluded from the study. In this case, the scale's factor load of 5 items $(\bar{X}=2,02, \sigma=0,94)$ varies between 0.70 and 0.82 . The Cronbach's Alpha value, which is the internal consistency coefficient of the scale, was calculated as 0.829. Confirmatory factor analysis was applied since the ranking was adapted into Turkish, and a new sample group was studied. The goodness of fit values obtained according to the confirmatory factor analysis results applied for the compulsive buying scale could not be verified in line with the data obtained from the initial model $\left(\chi^{2} / d f: 11,421\right.$, GFI:0,938, CFI: 0,823, NFI:0,916, TLI:0,884, RMSEA:0,120). After the modifications suggested by the model were carried out, the standardized factor loadings of the 6 th and 7 th items in the scale were excluded from the study because their factor loadings were below 0.5. It was seen that the values obtained as a result of repeated analysis provided an acceptable fit ( $\chi^{2} / d f: 2,956$, GFI:0,992, CFI: 0,992, NFI:0,988, TLI:0,985, RMSEA:0,052). As a result of the confirmatory factor analysis, standardized factor loads were between 0.60 and 0.78 (AVE=0.51, $\mathrm{CR}=0.84$ ). According to the results obtained, it was seen that the scale provided one-dimensional construct validity.

\subsubsection{Impulsive Buying Behaviour Scale}

A 5-item, 5-point Likert scale developed by Weun, Jones, and Betty (1997) was used to determine participants' impulsive buying behaviours. The Turkish adaptation, validity, and reliability analysis of the scale was performed by Torlak and Tiltay (2010). Before the scale was used within the scope of the research, permissions were obtained by Michael Jones and Muhammet A. Tiltay. The form of the expressions in the scale, adapted to Turkish respondents validly and reliably, was used in the same way. According to the explanatory factor analysis applied to the scale, the impulsive buying scale is unidimensional, and the total explained variance of the scale is 69.307\% (KMO:0.790, Bartlett $\chi 2: 1274.015$, p:0.000). It was excluded from the study because the factor loading of the 5 th item in the scale was less than 0.32 (Tabachnick \& Fidell, 2013). In this case, the factor load of the four expressions $(\bar{X}=2,29, \sigma=1,02)$ in the scale varies between 0.79 and 0.87 . The Cronbach's Alpha value, which is the internal consistency coefficient of the scale, was calculated as 0.851. Confirmatory factor analysis was applied since the scale was adapted into Turkish, and a new sample group was studied. Similar to other scales used in this study, it was observed that the first model obtained as a result of the confirmatory factor analysis applied to the impulsive buying behaviour scale was outside the acceptable goodness of fit values, and the modifications suggested by the model were applied. $\left(\chi^{2} / d f: 10,036, G F I: 0,971, C F I\right.$ : 0,967, NFI:0,963, TLI:0,933, RMSEA:0,112). As a result of the modifications, the 5th item of the impulsive buying behaviour scale was excluded from the study because the 
Küçükkambak, S.E. \& M. Süler (2022), "The Mediating Role of Impulsive Buying in The Relationship Between Fear of COVID-19 and Compulsive Buying: A Research on Consumers in Turkey”, Sosyoekonomi, 30(51), 165-197.

standardized factor load was below 0.5, the covariance between the 3rd and 4th items was drawn, and the analysis was repeated, revealing that the resulting values were in perfect agreement ( $\chi^{2} / d f: 0,032$, GFI:1,000, CFI:1,000, NFI:1,000, TLI:1,000, RMSEA:0,000). Standardized factor loads obtained from confirmatory factor analysis are between 0.63 and $0.90(A V E=0,57, C R=0,84)$. According to the confirmatory factor analysis, the construct validity of the measurement tools was ensured (Fornell \& Larcker, 1981; Byrne, 2016), and according to the calculated Cronbach's Alpha values, measurement scales are reliable (Robinson et al., 1991).

\subsection{Testing the Research Model}

The mediation effect in the research model was tested with the structural equation model. Before the analysis, the conformity of the data to the normal distribution was tested. The suitability of measurement tools to normal distribution was evaluated according to the kurtosis and skewness measures. Accordingly, since the calculated statistical value of each dimension is in the range of $+/-1.5$, it has been determined that the data are by the normal distribution (Tabanchnick \& Fidell, 2013). The research model created to determine the mediating effect of impulsive buying behaviour in the effect of fear of COVID-19 on compulsive buying behaviour was tested with the structural equation model, and the test result is summarized in Figure 1. Before testing the hypotheses in the research model with the structural equation model, confirmatory factor analysis was applied to the conceptual model as a whole. As a result of the analysis, it was determined that the model showed a good fit $\left(\chi^{2} / d f: 3,495\right.$, GFI:0,888, CFI:0,928, NFI:0,902, TLI:0,918, RMSEA:0,059).

Figure: 1

\section{Test of Research Model}

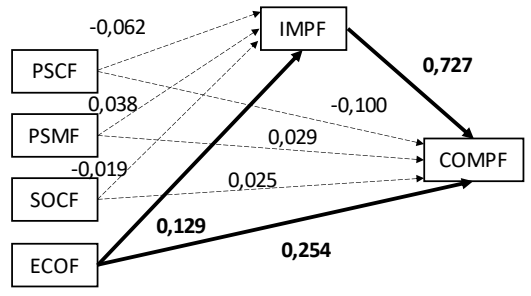

According to the analysis results, the psychological, psychosomatic, and social fears of the individuals participating in the research due to COVID-19 do not affect compulsive and impulsive buying behaviour; On the other hand, economic worries seem to be influential on impulsive and compulsive buying behaviours. In addition, it is seen that individuals' impulsive purchases affect their compulsive buying behaviours. On the other hand, according to the analysis results, it was seen that impulsive buying behaviour had a partial mediating effect on the effect of economic fear caused by COVID-19 on compulsive buying behaviour in individuals. 
Table: 1

Summary of The Research Model

\begin{tabular}{|c|c|c|c|c|c|}
\hline \multicolumn{6}{|c|}{ Model-1: The Mediation Effect of Impulsive Buying in The Effect of COVID-19 Fear on Compulsive Buying } \\
\hline Parameters & & & & $\beta$ & p \\
\hline Impulsive Buying $\leftarrow \mathrm{E}$ & nic Fear & & & 0,129 & $\mathbf{0 , 0 0 3}$ \\
\hline Compulsive Buying $\leftarrow$ & omic Fear & & & 0,254 & $* * *$ \\
\hline Compulsive Buying $\leftarrow$ & Isive Buying & & & 0,727 & $* * *$ \\
\hline \multicolumn{6}{|c|}{$\chi^{2} / d f: 3,451$ GFI:0,887 CFI:0,928 NFI:0,901 TLI:0,920 RMSEA:0,058 } \\
\hline & \multicolumn{2}{|c|}{ Direct Effect } & Indirect Effect & \multicolumn{2}{|c|}{ Total Effect } \\
\hline & Economic Fear & Impulsive Buying & Economic Fear & Economic Fear & Impulsive Buying \\
\hline Impulsive Buying & 0,129 & 0,000 & 0,000 & 0,129 & 0,00 \\
\hline Compulsive Buying & 0,254 & 0,727 & 0,094 & 0,348 & 0,727 \\
\hline
\end{tabular}

The model that measures the mediating effect of impulsive buying behaviour in the impact of the fear of COVID-19 on the compulsive buying behaviour of the individuals participating in the research was examined by multiple group analyses according to the gender of the participants. As a result of the study, the model for women is summarized in Figure 2, and the model for men is outlined in Figure 3.

\section{Figure:2}

The Mediation Effect of Impulsive Buying in The Effect of COVID-19 Fear on Compulsive Buying for Women

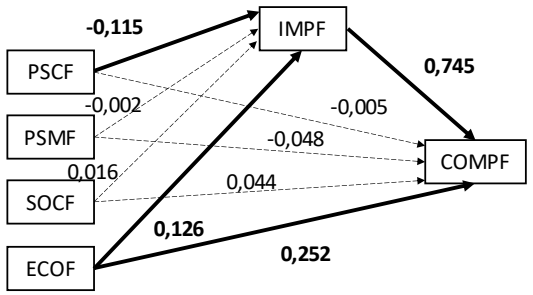

Figure: 3

The Mediation Effect of Impulsive Buying in The Effect of COVID-19 Fear on Compulsive Buying for Men

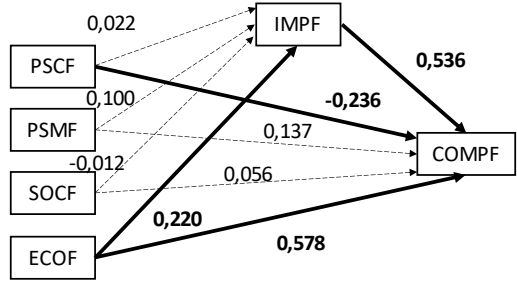

According to the analysis results, it was seen that the psychosomatic and social fears of the women participating in the study about COVID-19 did not affect impulsive and compulsive buying behaviour. However, it is seen that impulsive buying behaviour has a partial mediation effect on the effect of economic fears on compulsive buying behaviours of both men and women. In addition, the impact of women's psychological fears about 
COVID-19 on compulsive buying behaviour is fully mediated by impulsive buying behaviour. Women's psychological fears of COVID-19 negatively affect their impulsive and compulsive buying behaviour, while economic fears affect positively. In men, unlike women, the psychological fears caused by COVID-19 negatively affect compulsive buying behaviour. On the other hand, impulsive buying behaviour partially mediates the effect of economic concerns about COVID-19 on compulsive purchasing behaviour in male participants.

Table: 2

Summary of The Multigroup Analysis Model by Gender

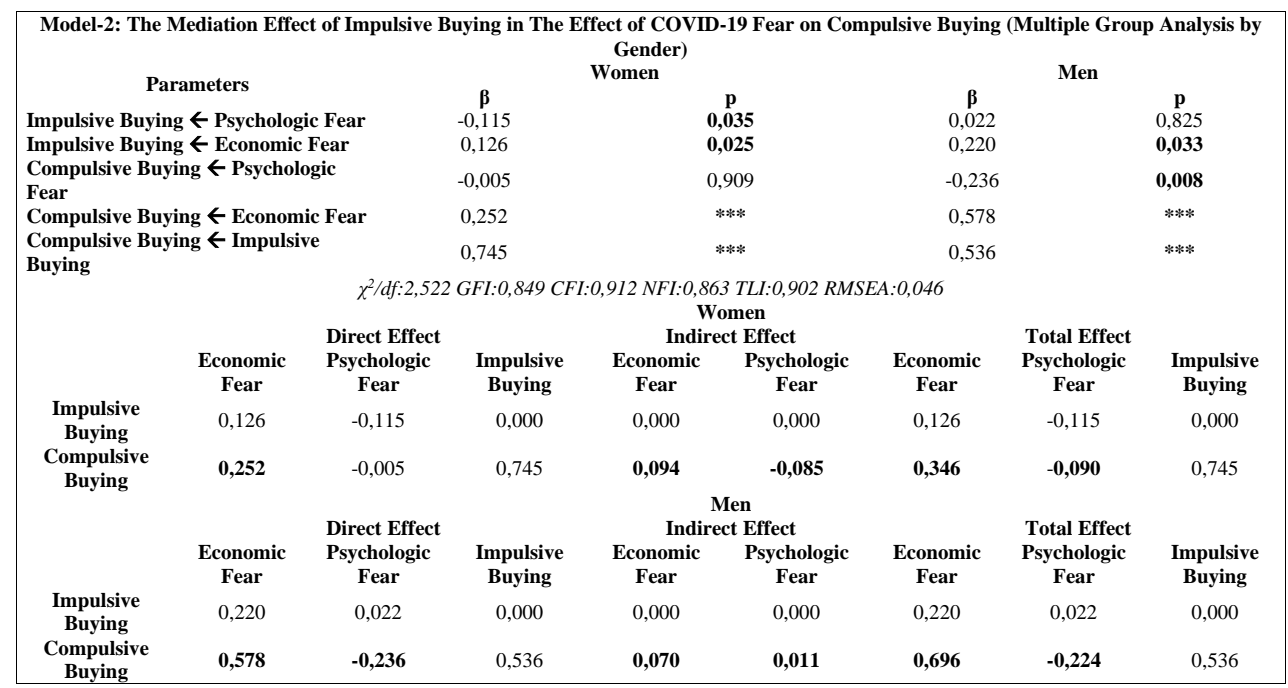

In the model created to measure the mediating effect of impulsive buying behaviour in the impact of the COVID-19 anxiety of the individuals participating in the research on compulsive buying behaviour, multiple group analysis was carried out according to the participants' environment shopped. The model that emerged from the study is summarized in Figure 4 and Figure 5. 
Figure: 4

The Mediation Effect of Impulsive Buying in The Effect of COVID-19 Fear on Compulsive Buying for Store Environment Shopping

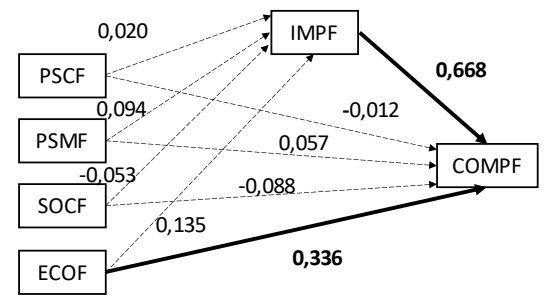

Figure: 5

The Mediation Effect of Impulsive Buying in The Effect of COVID-19 Fear on Compulsive Buying for Online Shopping

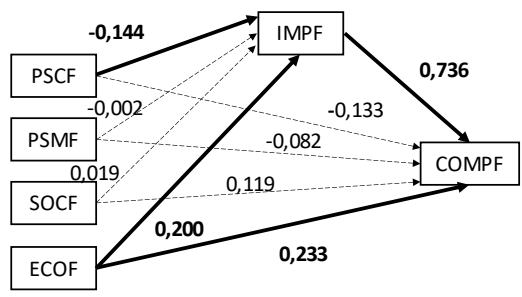

According to the analysis results, there is a partial mediation effect of the impulsive buying behaviour in the impact of the economic concerns of the individuals shopping in the store environment towards the COVID-19 on the compulsive buying behaviour.

Table: 3

Summary of The Multigroup Analysis Model by Shopping Environment

\begin{tabular}{|lccccccc|}
\hline \multicolumn{8}{|c}{ Model-3: The Mediation Effect of Impulsive Buying in The Effect of COVID-19 Fear on Compulsive Buying (Multiple Group Analysis by } \\
Shopping Place) \\
Store
\end{tabular}

According to the analysis results, impulsive buying behaviour has a full mediating effect on the psychological fear of COVID-19 on the compulsive purchasing behaviour of 
Küçükkambak, S.E. \& M. Süler (2022), “The Mediating Role of Impulsive Buying in The Relationship Between Fear of COVID-19 and Compulsive Buying: A Research on Consumers in Turkey”, Sosyoekonomi, 30(51), 165-197.

individuals who shop online. In contrast, impulsive buying behaviour has a partial mediating role in the effect of compulsive purchasing of economic fears. On the other hand, the financial worries of individuals who shop in a store environment affect their compulsive purchasing behaviour.

\section{Conclusion}

The majority of 721 individuals participating in this study are female, married, young adult, university graduate, working, and middle-income. During the COVID-19 process, the participants mainly shopped twice a week, bought food and cosmetic products, made their purchases online, and mostly preferred credit cards as the payment method. Participants' psychological fears of COVID-19 were high, and their psychosomatic fears were relatively low. It has been determined that the individuals participating in the research have higher impulsive buying tendencies than compulsive buying tendencies during the COVID-19 process. In addition, the rate of excessive buyers $(2.5<\bar{X}<4)$ among the total participants was $14.2 \%(n=103)$, while the rate of those who made pathological compulsive purchases $(\bar{X} \geq 4)$ was $5.9 \%(n=43)$ has been identified. On the other hand, the rate of excessive impulsive buyers $(2.5<\bar{X}<4)$ was $21.9 \%(n=158)$, while the rate of pathologically impulsive buyers $(\bar{X} \geq 4)$ was $10.1 \%(n=73)$ seen.

According to the results of the analysis, women's psychological ( $p=0,002, t=3,041$, $\bar{X}=3,93)$ and psychosomatic fears $(p=0,038, t=2,76, \bar{X}=1,86)$ of COVID-19 are higher than men. On the other hand, women's compulsive $(\mathrm{p}=0,000, \mathrm{t}=4,897, \overline{\mathrm{x}}=2,09)$ and impulsive buying behaviours $(\mathrm{p}=0,000, \mathrm{t}=3,962, \overline{\mathrm{x}}=2,36)$ are higher than men during the pandemic process. Singles have higher averages for compulsive $(p=0,000, t=-3,739, \bar{X}=2,21)$ and impulsive buying behaviours ( $p=0,001, t=-3,416, \bar{X}=2,47$ ) compared to married individuals. On the other hand, the average of online shoppers for compulsive $(p=0,000, t=-5,762$, $\bar{X}=2,16)$ and impulsive buying behaviour $(p=0,000, t=-4,667, \bar{X}=2,43)$ is higher than those who prefer to shop from the store. While social fears $(F=4,588, p=0,001, \bar{x}=3,52)$ of individuals aged 62 and above are higher than individuals aged 29-39, compulsive $(F=12,178, \quad p=0,000, \bar{X}=2,38)$ and impulsive buying behaviours $(F=7,470, p=0,000$, $\bar{X}=2,51)$ of individuals aged 18-28 are higher compared to individuals aged 62 and above. Individuals with a monthly income of $2.500 \mathrm{TL}$ or less have psychological $(F=6.582$, $p=0.000, \bar{X}=4.15)$, social $(F=8.415, p=0.000, \bar{X}=3.49)$, and economic fears $(F=2.414$, $p=0.048, \bar{X}=2.29$ ) is higher compared to individuals with higher income. In addition, individuals with a monthly income of 2,500 TL or less have a higher average for compulsive buying behaviour $(F=2.991, p=0.018, \bar{X}=2.20)$ compared to individuals with an income of 5.001-7.500 TL. On the other hand, the average impulsive buying behaviours of individuals with an income of $10.001 \mathrm{TL}$ or more $(F=2.898, p=0.021, \bar{X}=2.75)$ is higher than individuals with an income of 2.500TL or less.

It has been determined that individuals with doctoral-level education have higher social fears $(F=3.759, p=0.002, \bar{X}=3.71)$ towards COVID-19 compared to individuals with 
undergraduate education. In addition, it has been observed that individuals with master's degree education have lower economic fears $(F=4.022, p=0.001, \bar{X}=2.05)$ compared to individuals with an associate degree or doctoral education. The impulsive buying behaviours of individuals with primary education levels during the pandemic process $(F=4.022$, $p=0.001, \bar{X}=2.30$ ) are lower than individuals with higher education. It was determined that the psychosomatic fears of the housewife's participants $(F=2.912, p=0.008, \bar{X}=2.93)$ were higher than the other individuals. On the other hand, individuals working as civil servants were found to have lower social fears $(F=3.634, p=0.001, \bar{X}=2.99)$ compared to students or retired individuals. It is observed that the economic concerns of retired individuals $(F=2.773, p=0.011, \bar{X}=2.45)$ are higher than the self-employed individuals. It is seen that the compulsive buying tendencies of retired individuals participating in the research $(F=5.858, p=0.000, \bar{x}=1.66)$ in their shopping during the pandemic period have a lower average than students, self-employed or civil servants. In addition, it is observed that the students' impulsive tendencies $(\mathrm{F}=4.025, \mathrm{p}=0.001, \overline{\mathrm{X}}=2.49)$ during the pandemic period are higher than the self-employed or retired individuals.

Among the participants, the fear of COVID-19 of the individuals who use a credit card as a payment method $(\mathrm{p}<0.05)$ is higher than those who prefer to pay cash. Similarly, compulsive $(F=4.172, p=0.002, \bar{X}=2.07)$ and impulsive buying behaviours $(F=4.074$, $p=0.003, \bar{x}=2.36$ ) in the COVID-19 process of individuals who prefer credit cards as a payment method higher than individuals who prefer to pay cash. In the COVID-19 process, individuals who shop once every day have a higher tendency to buy compulsive $(F=5,379$ $p=0,000, \bar{X}=2,63)$ and impulsive $(F=6,864, p=0,000, \bar{X}=2,95)$ compared to individuals who shop once a week, once a month, or twice a month. It was observed that individuals who buy food products frequently $(F=2.817, p=0.007, \bar{X}=3.06)$ have lower social fears compared to individuals who buy cleaning products. The compulsive purchasing tendencies of the participants $(F=6.399, p=0.000, \bar{X}=3.58)$ stated that they most frequently purchased the paper and cosmetic products during the COVID-19 process were higher than the individuals who bought food and cleaning products. In addition, individuals who frequently purchase mother or baby care products from the participants have higher impulsive purchasing tendencies during the COVID-19 process $(F=2.784, p=0.007, \quad \bar{X}=2.82)$ compared to individuals who buy cleaning products.

Table: 4

\section{Hypothesis Test Results}

\begin{tabular}{|c|c|c|c|c|c|}
\hline \multirow{2}{*}{ Hypotheses } & \multirow{2}{*}{$\begin{array}{c}\text { Research Model } \\
\text { General } \\
\end{array}$} & \multicolumn{2}{|c|}{ Multi-Group Analysis by Gender } & \multicolumn{2}{|c|}{ Multi-Group Analysis by Shopping Environment } \\
\hline & & Women & Men & Store Shopping & Online Shopping \\
\hline H1 & Rejected & Accepted & Rejected & Rejected & Accepted \\
\hline H2 & Rejected & Rejected & Rejected & Rejected & Rejected \\
\hline H3 & Rejected & Rejected & Rejected & Rejected & Rejected \\
\hline H4 & Accepted & Accepted & Accepted & Rejected & Accepted \\
\hline H5 & Rejected & Rejected & Accepted & Rejected & Rejected \\
\hline H6 & Rejected & Rejected & Rejected & Rejected & Rejected \\
\hline H7 & Rejected & Rejected & Rejected & Rejected & Rejected \\
\hline H8 & Accepted & Accepted & Accepted & Accepted & Accepted \\
\hline H9 & Accepted & Accepted & Accepted & Accepted & Accepted \\
\hline H10 & Accepted & Accepted & Accepted & Rejected & Accepted \\
\hline
\end{tabular}


Küçükkambak, S.E. \& M. Süler (2022), "The Mediating Role of Impulsive Buying in The Relationship Between Fear of COVID-19 and Compulsive Buying: A Research on Consumers in Turkey”, Sosyoekonomi, 30(51), 165-197.

The hypotheses tested in detail according to the multi-group analysis in the study are summarized in Table 4. Within the scope of the research, it has been seen that the fear of individuals due to COVID-19 affects compulsive buying behaviour, and impulsive buying behaviour has a partial mediator role in this interaction. According to the model, $27 \%$ of individuals' economic concerns on compulsive buying is mediated by impulsive buying behaviour. It is seen that the research model works differently according to the gender of the participants. Psychological fears caused by COVID-19 affect impulsive and compulsive purchasing behaviour in women. In addition, 94\% of the effect of women's psychological fears on compulsive purchasing behaviour arises due to the mediating effect of impulsive buying behaviour. In addition, $27.1 \%$ of the impact of women's economic concerns on compulsive buying behaviour emerged due to the mediating influence of impulsive buying behaviour. In men, $10 \%$ of the effect of financial fear on compulsive buying behaviour is mediated by impulsive buying behaviour.

Moreover, it is seen that the effect of impulsive buying behaviour seen in women on compulsive buying behaviour is more. In men, it is observed that the psychological fear caused by COVID-19 affects compulsive purchasing behaviour more strongly and negatively than women. In addition, economic fears experienced by male participants were found to affect impulsive and compulsive buying behaviours more strongly than female participants.

It was observed that the research model produced different results according to the environment in which the participants shopped during the pandemic period. It has been observed that the economic fear of COVID-19 that individuals who prefer to do their shopping in the store environment positively affect compulsive buying. Moreover, it has been observed that the psychological anxiety caused by COVID-19 affects compulsive buying behaviour in individuals who prefer to do their shopping on the internet. The impulsive buying behaviour has a full mediator effect in this interaction. In addition, 38.6\% of the impact of the economic fears of online shoppers on compulsive buying behaviour is realized through impulsive buying. In addition, while psychological fears negatively affect impulsive and compulsive buying in online individuals, economic fears positively affect them.

\section{Discussion and For Future Research}

This research has three distinctive aspects. This study examined the effects of different types of fears caused by COVID-19 on compulsive buying behaviour. The second unique aspect of the study is the effects of various concerns that create a negative mood on impulsive buying behaviour. Some of the "dark motives" that affect the impulse buying behaviour of consumers are revealed. Finally, the effects of two different impulsive based buying behaviours, unplanned and impulsive shopping types, are examined.

Considering the shopping frequency of excessive buyers and compulsive buyers at the pathological level, it is seen that they shop twice a week, similar to the studies of 
Küçükkambak, S.E. \& M. Süler (2022), “The Mediating Role of Impulsive Buying in The Relationship Between Fear of COVID-19 and Compulsive Buying: A Research on Consumers in Turkey”, Sosyoekonomi, 30(51), 165-197.

Christenson et al. (1994) and Schlosser et al. (1994). On the other hand, the increase in cosmetic products in compulsive purchases is similar to the study of McElroy et al. (1994). However, disinfectant products were also evaluated in cosmetic products in the current study. It was interpreted that the factor causing this situation was related to various psychological concerns caused by COVID-19. In addition, the increase in compulsive purchases of paper products is thought to be related to hoarding behaviour. However, since the stocking behaviour of individuals was not examined in the current study, it is necessary to investigate hoarding behaviour caused by the fear of COVID-19 in future studies to reach a definitive conclusion.

While the coronavirus pandemic increased psychological fears in the participants, psychosomatic fears remained low compared to other worries. This result is consistent with the results of Baloğlu et al. (2021). Since no study deals with consumers' impulsive and compulsive buying behaviours together in the COVID-19 process, the fact that the average for impulsive buying behaviour is higher than compulsive buying behaviour does not allow comparison. Whether this result is a general trend or a situation-specific to this period is open to debate. For example, Japutra et al. (2019) found that the averages for impulsive buying behaviour were higher than the averages for compulsive buying behaviour in their study, where they evaluated the impulsive and compulsive buying variables together.

For this reason, it will contribute to the literature to consider the effects of negative emotions together with impulsive and compulsive buying behaviours in future studies. The percentage of compulsive buyers at the pathological level $(n=43,5.9 \%, \bar{x}=4.43)$ among individuals participating in the study is similar to the result in the US population in the study of Koran et al. (2006). On the other hand, it is expected that the current calculation will contribute to the literature since no estimate has been made about compulsive receptors at the pathological level in the general population in Turkey recently. Shortly, the increase in studies examining the compulsive buying behaviour of consumers in the COVID-19 process will contribute to the literature in terms of revealing the effect of the pandemic on compulsive buying.

In the present study, the fact that impulsive buying behaviour was higher in women than in men was interpreted as a result similar to Chen's (2001) research. This has been associated with shopping is generally more liked by women; women both spend more time and are willing to do so, shopping, browsing stores, examining product shelves and prices, and researching products. On the other hand, it is thought that this result is related to the fact that women are generally the shoppers in terms of the roles women and men assume in society. In the current study, the fact that women's average for compulsive buying is higher than men's is in line with the reflections in the literature (Roberts, 1998; Yurchisin \& Johnson, 2004; Dittmar, 2005). The fact that the mean of single individuals for compulsive buying is high in the current study is in line with the investigations of Lejoyeux et al. (1999, 2007). 
Küçükkambak, S.E. \& M. Süler (2022), "The Mediating Role of Impulsive Buying in The Relationship Between Fear of COVID-19 and Compulsive Buying: A Research on Consumers in Turkey”, Sosyoekonomi, 30(51), 165-197.

On the other hand, the high average of single participants' impulsive buying behaviour is one of the surprising results obtained from this study. Because Özoğlu and Bülbül (2017) found in their research that the impulse buying behaviour of married individuals is higher, the difference seen in this study may be related to the selected population or the period in which the survey was conducted, as well as different psychological variables that may have affected the impulse buying behaviour of single individuals. To clarify this difference, measuring the mediation effect of other psychological variables in studies dealing with consumers' impulsive buying behaviour in terms of marital status will contribute to the literature.

One of the surprising results of this study is that the compulsive and impulsive purchases of the individuals participating in the research, who prefer to shop mainly online during the COVID-19 process, are higher than those who like to shop from the store. It is thought that the reasons such as the curfew restrictions of individuals and the widespread use of door-to-door service by online shopping sites as of the period of the research increased these purchases. On the other hand, like Faber and O'Guinn $(1989,2008)$ suggested, the loneliness and social isolation experienced by individuals during the COVID-19 process affected their psychological balance. Therefore, it was interpreted as increasing online compulsive and impulsive purchases. However, studies comparing compulsive and impulsive buying behaviour with online and store shopping should soon increase to reach comparative and supportive information about this situation.

Similarly, the compulsive and impulsive purchasing averages of the participants who generally prefer to pay by credit card during the pandemic period are higher than the individuals who prefer to pay in cash, which is in line with the study of Roberts and Jones (2001). In addition, the increase in shopping with contactless credit cards during the COVID19 process and the fact that shopping is usually done online due to curfews have been associated with this situation. The higher fear of COVID-19 among those who shop with credit cards than those who prefer the cash method has also been associated with the same reasons.

Considering the differences between the age of the participants and their fears about COVID-19, it is associated with the fact that middle-aged individuals have higher social anxiety than young individuals, and these individuals are more affected by curfews. In addition, young individuals' compulsive and impulsive purchases are higher than those of middle age, which is also similar to the literature (Sharma, 2011; Black, 2007). In addition, identical to the result obtained from Black's (2001) study, compulsive buying behaviours of low-income individuals are higher than those of higher-income individuals in the current study. Low-income individuals with a heightened fear of COVID-19 have been associated with limited opportunities and believe they can lose them more easily. In addition, the high level of impulsive purchases in individuals with high-income groups, as stated by Beatty and Ferrel (1998), is associated with an increase in unplanned purchases in parallel with the rise in income level. Although a general inference between individuals' education levels and spontaneous purchasing behaviour has not been formed in the literature yet, unlike Yang et 
Küçükkambak, S.E. \& M. Süler (2022), “The Mediating Role of Impulsive Buying in The Relationship Between Fear of COVID-19 and Compulsive Buying: A Research on Consumers in Turkey”, Sosyoekonomi, 30(51), 165-197.

al. (2011), some differences were found in the present study. Accordingly, the higher the education level, the higher the impulsive buying tendency. More research is needed to generalize about the education variable. On the other hand, the relationships between the participants' or participants' or retirement status and their impulse buying behaviours were consistent with the results obtained from the age variable.

Similar to the conclusion reached by Gallagher et al. (2017), in the current study, the social anxiety of individuals did not affect their purchasing behaviour. However, economic concerns experienced by individuals increased impulsive and compulsive purchasing behaviours. In addition, the financial stress experienced increased impulsive buying behaviour and increased compulsive buying. In this study, the positive effect of impulsive buying on compulsive buying $(\beta=0.727, \mathrm{p}<.01)$ was higher in the study of Shehzedi et al. (2016) and Sun et al. (2004). It is thought that this situation is caused by the fear of COVID19 increasing the impulsive buying behaviour in individuals, causing more loss of impulse control over time, and the effect of social isolation and loneliness.

According to the gender factor, which is frequently examined by researchers in impulsive buying behaviour, in the present study, women's psychological concerns negatively affected their impulsive buying behaviour. This showed that negative emotions affect impulsive and compulsive buying in a reducing way. According to this result, female participants are negatively affected by the fear of catching coronavirus or the fear of their relatives getting this disease and reducing their unplanned purchasing behaviour. Similarly, psychological anxiety caused by the coronavirus negatively affected compulsive buying in men. However, the present study did not support compulsive and impulsive purchasing behaviour, which is seen as one way to avoid negative emotions in previous studies. The fact that individuals reduce their impulsive and compulsive purchases due to the psychological concerns they experience may suggest more than one reason. Since psychological anxiety towards COVID-19 is generally related to the fear of individuals or their relatives contracting the disease, it can reduce excessive purchases and contact with products, outlets, or vendors, thus reducing the likelihood of contracting the disease.

However, economic concerns caused by COVID-19 strengthened compulsive buying behaviour in women and men participating in the research. This situation has been interpreted as stock problems such as scarcity anxiety experienced by individuals, depletion of food, drink, and cleaning materials, triggering hoarding and stocking behaviour (Hamilton, 2020; Jezewska-Zychowicz et al., 2020; Sheth, 2020). Another surprising result obtained from the research is that individuals' economic concerns trigger impulsive buying, resulting in compulsive buying. This observed situation has also been associated with the stocking behaviour of individuals who shop online. In the future, examining the effects of different psychological variables in studies that associate the concerns caused by COVID19 with impulsive buying behaviours will contribute to the literature in terms of clarifying consumer purchasing behaviours. 
Küçükkambak, S.E. \& M. Süler (2022), "The Mediating Role of Impulsive Buying in The Relationship Between Fear of COVID-19 and Compulsive Buying: A Research on Consumers in Turkey”, Sosyoekonomi, 30(51), 165-197.

\section{References}

Arpaci, I. et al. (2020), "The development and initial tests for the psychometric properties of the COVID-19 phobia scale", Personality and Individual Differences, 164, 110108.

Baloglu, M. et al. (2021), "Psychological and socio-economic effects of the COVID-19 pandemic on Turkish population", Emerging Technologies During the Era of COVID-19 Pandemic, 348, 245.

Beatty, S.E. \& M.E. Ferrell (1998), “Impulse buying: modeling its precursors”, Journal of Retailing, 74(2), 169-19.

Billore, S. \& T. Anisimova (2021), "Panic buying research: a systematic literature review and future research agenda”, International Journal of Consumer Studies, Special Issue, 1-28.

Black, D.W. (2001), “Compulsive buying disorder”, Cns Drugs, 15(1), 17-27.

Black, D.W. (2007), "Compulsive buying disorder: a review of the evidence", Cns Spectrums, 12(2), 124-132.

Black, D.W. et al. (1998), "Family history and psychiatric comorbidity in persons with compulsive buying: preliminary findings", American Journal of Psychiatry, 155(7), 960-963.

Byrne, B.M. (2016), Structural equation modeling with amos basic concepts, applications, and programming (multivariate applications series), Third Edition, Routledge.

Campbell, C. (2000), "Shopaholics, spendaholics and the question of gender", in: A.L. Benson (ed.), I shop, therefore I am: compulsive buying and the search for self (57-75), Aronson Press.

Chang, H.J. et al. (2011), "Application of the stimulus-organism-response model to the retail environment: the role of hedonic motivation in impulse buying behaviour", The International Review of Retail, Distribution and Consumer Research, 21(3), 233-249.

Chen, M.H. (2001), "The determinants and traits of impulsive buying behaviour”, Journal of Takming University, 17, 59-74.

Chen, T. (2008), "Impulse purchase varied by products and marketing channels", Journal of International Management Studies, 3(1), 154-161.

Chenarides, L. et al. (2021), "Food consumption behaviour during the COVID-19 pandemic", Agribusiness, 37(1), 44-81.

Christenson, G.A. et al. (1994), "Descriptive characteristics and psychiatric comorbidity of compulsive buying", Journal of Clinical Psychiatry, 55, 5-11.

Clover, V.T. (1950), "Relative importance of impulse-buying in retail stores", Journal of Marketing, 15(1), 66-70.

Coley, A. \& B. Burgess (2003), "Gender differences in cognitive and affective impulse buying", Journal of Fashion Marketing and Management: An International Journal, 7(3), 282295.

Çelik, S. \& G.G. Köse (2021), "Mediating effect of intolerance of uncertainty in the relationship between coping styles with stress during pandemic (COVID-19) process and compulsive buying behaviour", Progress in Neuro-Psychopharmacology and Biological Psychiatry, 110, 110321.

D'Astous, A. (1990), “An inquiry into the compulsive side of "normal" consumers", Journal of Consumer Policy, 13(1), 15-31. 
Küçükkambak, S.E. \& M. Süler (2022), “The Mediating Role of Impulsive Buying in The Relationship Between Fear of COVID-19 and Compulsive Buying: A Research on Consumers in Turkey”, Sosyoekonomi, 30(51), 165-197.

Darrat, A.A. et al. (2016), "How impulse buying influences compulsive buying: the central role of consumer anxiety and escapism", Journal of Retailing and Consumer Services, 31, 103108.

Dawson, S. \& M. Kim (2009), "External and internal trigger cues of impulse buying online", Direct Marketing: An International Journal, 3(1), 20-34.

Dell'Osso, B. et al. (2006), "Epidemiologic and clinical updates on impulse control disorders: a critical review", European Archives of Psychiatry and Clinical Neuroscience, 256(8), 464-475.

Desarbo, W.S. \& E.A. Edwards (1996), “Typologies of compulsive buying behaviour: a constrained clusterwise regression approach”, Journal of Consumer Psychology, 5(3), 231-262.

Dey, D.K. \& A. Srivastava (2017), "Impulse buying intentions of young consumers from a hedonic shopping perspective", Journal of Indian Business Research, 9(4), 266-282.

Dietrich, A. et al. (2020), "News and Uncertainty About COVID-19: Survey Evidence and ShortRun Economic Impact”, Working Paper, Federal Reserve Bank of Cleveland.

Dittmar, H. (2005), "Compulsive buying-a growing concern? An examination of gender, age, and endorsement of materialistic values as predictors", British Journal of Psychology, 96(4), 467-491.

Dittmar, H. et al. (1995), "Gender identity and material symbols: objects and decision considerations in impulse purchases", Journal of Economic Psychology, 16(3), 491-511.

Dittmar, H. et al. (1996), “Objects, decision considerations and self-image in men's and women's impulse purchases", Acta Psychologica, 93(1-3), 187-206.

Donthu, N. \& A. Gustafsson (2020), "Effects of COVID-19 on business and research", Journal of Business Research, 117, 284.

Edwards, E.A. (1992), "The measurement and modeling of compulsive buying behaviour", Dissertation Abstracts International, 53(11-A),

Edwards, E.A. (1993), "Development of a new scale for measuring compulsive buying behaviour", Financial Counseling and Planning, 4(1), 67-84.

Faber, R.J. \& T.C. O'Guinn (1988), "Expanding the view of consumer socialization: a nonutilitarian mass-mediated perspective", Research in Consumer Behaviour, 3, 49-77.

Faber, R.J. \& T.C. O’Quinn (1992), “A clinical screener for compulsive buying”, Journal of Consumer Research, 19(3), 459-469.

Faber, R.J. (2010), "Diagnosis and Epidemiology of Compulsive Buying”, in: A. Müller \& J.E. Mitchell (eds.), Compulsive Buying: Clinical Foundations and Treatment (3-19), Routledge.

Faber, R.J. et al. (1987), “Compulsive Consumption”, in: M. Wallendorf \& P. Anderson (eds.), Advances in Consumer Research (132-135), Provo, UT: Association for Consumer Research.

Faber, R.J. et al. (1995), “Two forms of compulsive consumption: comorbidity of compulsive buying and binge eating", Journal of Consumer Research, 22, 296-304.

Finke, M.S. \& S.J. Huston (2003), "Factors affecting the probability of choosing a risky diet", Journal of Family and Economic Issues, 24, 291-303.

Fornell, C. \& D.F. Larcker (1981), "Evaluating structural equation models with unobservable variables and measurement error", Journal of Marketing Research, 18(1), 39-50. 
Küçükkambak, S.E. \& M. Süler (2022), "The Mediating Role of Impulsive Buying in The Relationship Between Fear of COVID-19 and Compulsive Buying: A Research on Consumers in Turkey”, Sosyoekonomi, 30(51), 165-197.

Foroughi, A. et al. (2013), "Impulse buying behaviour and moderating role of gender among Iranian shoppers", Journal of Basic and Applied Scientific Research, 3(4), 760-769.

Frost, R.O. et al. (2002), "Compulsive buying, compulsive hoarding, and obsessive-compulsive disorder", Behaviour Therapy, 33(2), 201-214.

Gallagher, C.E. et al. (2017), “'I fear, therefore, I shop!' Exploring anxiety sensitivity in relation to compulsive buying", Personality and Individual Differences, 104, 37-42.

Gardner, M.P. \& D.W. Rook (1988), "Effects of impulse purchases on consumers' affective states”, ACR North American Advances, 15, 127-130.

Glatt, M.M. \& C.C. Cook (1987), "Pathological spending as a form of psychological dependence", British Journal of Addiction, 82, 1257-1258.

Goldsmith, T. \& S. Mcelroy (2000), "Compulsive Buying: Associated Disorders and Drug Treatment", in: A.L. Benson (ed.), I shop, therefore I am: compulsive buying and the search for self (217-242), Aronson Press.

Grashuis, J. et al. (2020), "Grocery shopping preferences during the COVID-19 pandemic", Sustainability, 12(13), 5369.

Hair, J.F.J. et al. (2014), Multivariate data analysis, Seventh Edition Prentice Hall.

Hamilton, R. (2021), "Scarcity and coronavirus", Journal of Public Policy \& Marketing, 40(1), 99100.

Hanley, A. \& M.S. Wilhelm (1992), “Compulsive buying: an exploration into self-esteem and money attitudes", Journal of Economic Psychology, 13(1), 5-18.

Haugtvedt, C.P. et al. (2008), "Compulsive Buying: Review and Reflection”, in: R.J. Faber \& T.C. O'Guinn (eds.), Handbook of Consumer Psychology (1027-1044), Routledge.

Hausman, A. (2000), "A multi-method investigation of consumer motivations in impulse buying behaviour", Journal of Consumer Marketing, 17(5), 403-419.

Hirschman, E.C. (1992), "The consciousness of addiction: toward a general theory of compulsive consumption", Journal of Consumer Research, 19(2), 155-179.

Hoch, S.J. \& G.F. Loewenstein (1991), “Time-inconsistent preferences and consumer self-control”, Journal of Consumer Research, 17(4), 492-507.

Hubert, M. et al. (2013), "Neural correlates of impulsive buying tendencies during perception of product packaging", Psychology \& Marketing, 30(10), 861-873.

Islam, T. et al. (2021), "Panic buying in the COVID-19 pandemic: a multi-country examination", Journal of Retailing and Consumer Services, 59, 102357.

Japutra, A. et al. (2019), "Self-congruence, brand attachment and compulsive buying", Journal of Business Research, 99, 456-463.

Jeffrey, S.A. \& R. Hodge (2007), "Factors influencing impulse buying during an online purchase", Electronic Commerce Research, 7(3), 367-379.

Jeżewska-Zychowicz, M. et al. (2020), “Consumers' fears regarding food availability and purchasing behaviours during the Covid-19 pandemic: the importance of trust and perceived stress", Nutrients, 12(9), 2852, 1-14.

Johnson, T. \& J. Attmann (2009), "Compulsive buying in a product specific context: clothing", Journal of Fashion Marketing and Management: An International Journal, 13(3), 394405. 
Küçükkambak, S.E. \& M. Süler (2022), “The Mediating Role of Impulsive Buying in The Relationship Between Fear of COVID-19 and Compulsive Buying: A Research on Consumers in Turkey”, Sosyoekonomi, 30(51), 165-197.

Jones, M.A. et al. (2003), “The product-specific nature of impulse buying tendency”, Journal of Business Research, 56(7), 505-511.

Kacen, J.J. \& J.A. Lee (2002), “The influence of culture on consumer impulsive buying behaviour”, Journal of Consumer Psychology, 12(2), 163-176.

Karbasivar, A. \& H. Yarahmadi (2011), "Evaluating effective factors on consumer impulse buying behaviour", Asian Journal of Business Management Studies, 2(4), 174-181.

Khan, M.R. et al. (2021), "A study of changing consumer behaviour of four metro cities in India during COVID-19 pandemic", Wesleyan Journal of Research, 13(57), 81-92.

Kieffer, K.M. (1998), "Orthogonal versus oblique factor rotation: a review of the literature regarding the pros and cons", Paper Presented at The Annual Meeting of The American Educational Research Association, New Orleans.

Kivetz, R. \& Y. Zheng (2006), "Determinants of justification and self-control”, Journal of Experimental Psychology: General, 135(4), 572.

Koran, L. (1999), Obsessive compulsive and related disorders in adults, Cambridge University Press.

Koran, L.M. et al. (2006), "Estimated prevalence of compulsive buying behaviour in the united states", American Journal of Psychiatry, 163(10), 1806-1812.

Krafft, J. et al. (2020), "An ecological momentary assessment study investigating the function of hoarding", Behaviour Therapy, 51(5), 715-727.

Krueger, D. (1988), "On compulsive shopping and spending: a psychodynamic inquiry”, American Journal of Psychotherapy, 42, 574-585.

Kwak, H. et al. (2004), "Compulsive comorbidity and its psychological antecedents: a cross-cultural comparison between the US and South Korea", Journal of Consumer Marketing, 21(6), 418-434.

Laato, S. et al. (2020), "Unusual purchasing behaviour during the early stages of the COVID-19 pandemic: the stimulus-organism-response approach", Journal of Retailing and Consumer Services, 57, 102224.

Lee, G.Y. \& Y. Yi (2008), "The effect of shopping emotions and perceived risk on impulsive buying: the moderating role of buying impulsiveness trait", Seoul Journal of Business, 14(2), 67-92.

Lee, S.H. \& J.E. Workman (2018), "Consumer Tendency To Regret, Compulsive Buying, Gender, and Fashion Time-of-Adoption Groups", International Journal of Fashion Design, Technology and Education, 11(3), 265-276.

Lejoyeux, M. \& A. Weinstein (2010), "Compulsive buying", The American Journal of Drug and Alcohol Abuse, 36(5), 248-253.

Lejoyeux, M. et al. (1996), "Phenomenology and psychopathology of uncontrolled buying", The American Journal of Psychiatry, 153(12), 1524-1529.

Lejoyeux, M. et al. (2005), "Study of compulsive buying in patients presenting obsessive-compulsive disorder", Comprehensive Psychiatry, 46(2), 105-110.

Lejoyeux, M. et al. (2007), "Prevalence of compulsive buying among customers of a Parisian general store", Comprehensive Psychiatry, 48(1), 42-46. 
Küçükkambak, S.E. \& M. Süler (2022), “The Mediating Role of Impulsive Buying in The Relationship Between Fear of COVID-19 and Compulsive Buying: A Research on Consumers in Turkey”, Sosyoekonomi, 30(51), 165-197.

Li, J. et al. (2020), "Changing grocery shopping behaviours among chinese consumers at the outset of the COVID-19 outbreak", Tijdschrift Voor Economische En Sociale Geografie, 111(3), 574-583.

Liang, Y.P. (2012), "The relationship between consumer product involvement, product knowledge and impulsive buying behaviour", Procedia-Social and Behavioural Sciences, 57, 325330.

Lim, P.L. \& R. Yazdanifard (2015), "What internal and external factors influence impulsive buying behaviour in online shopping?", Global Journal of Management and Business Research, 15(5), 25-32.

Lopes, B. et al. (2020), "Paranoia, hallucinations and compulsive buying during the early phase of the COVID-19 outbreak in The United Kingdom: a preliminary experimental study", Psychiatry Research, 293, 113455.

Marlatt, G.A. et al. (1988), “Addictive behaviours: etiology and treatment”, Annual Review of Psychology, 39(1), 223-252.

Mcelroy, S.L. et al. (1991), "Treatment of compulsive shopping with antidepressants: a report of three cases", Annals of Clinical Psychiatry, 3(3), 199-204.

McElroy, S.L. et al. (1994), "Compulsive buying: a report of 20 cases”, The Journal of Clinical Psychiatry, 55(6), 242-248.

Melo, G. (2020), “The path forward: us consumer and food retail responses to COVID-19”, Choices, $35(3)$.

Miao, M. et al. (2019), "The effects of personality, culture and store stimuli on impulsive buying behaviour: Evidence from emerging market of Pakistan”, Asia Pacific Journal of Marketing and Logistics, 32(1), 188-204.

Mohan, G. et al. (2013), “Impact of store environment on impulse buying behaviour”, European Journal of Marketing, 47(10), 1711-1732.

Mueller, A. et al. (2011), "Depression, materialism, and excessive internet use in relation to compulsive buying", Comprehensive Psychiatry, 52(4), 420-424.

Muruganantham, G. \& R.S. Bhakat (2013), “A review of impulse buying behaviour”, International Journal of Marketing Studies, 5(3), 149.

Müller, A. et al. (2015), “Compulsive buying”, The American Journal on Addictions, 24(2), 132-137.

Nakano, S. et al. (2021), Consumer panic buying: understanding its behavioural and psychological aspects, Available at SSRN 3796825.

Neuner, M. et al. (2005), "Compulsive buying in maturing consumer societies: an empirical reinquiry", Journal of Economic Psychology, 26(4), 509-522.

O’Guinn, T.C. \& R.J. Faber (1989), “Compulsive buying: A phenomenological exploration”, Journal of Consumer Research, 16(2), 147-157.

Park, H.J. \& L.D. Burns (2005), "Fashion orientation, credit card use, and compulsive buying”, Journal of Consumer Marketing, 22(3), 135-141.

Peck, J. \& T.L. Childers (2006), "If i touch it i have to have it: individual and environmental influences on impulse purchasing", Journal of Business Research, 59(6), 765-769.

Petersen, A. (2020), "Your video therapist will see you now; sessions have gone virtual amid the coronavirus pandemic, raising new challenges", Wall Street Journal, April 26. 
Küçükkambak, S.E. \& M. Süler (2022), “The Mediating Role of Impulsive Buying in The Relationship Between Fear of COVID-19 and Compulsive Buying: A Research on Consumers in Turkey”, Sosyoekonomi, 30(51), 165-197.

Popkin, M.K. (1989), "Impulse control disorders not elsewhere classified”, in: H.I. Kaplan \& B.J. Sadock (eds.), Comprehensive Textbook of Psychiatry (1145-1155), Williams \& Wilkins.

Pradhan, V. (2016), "Study on impulsive buying behaviour among consumers in supermarket in kathmandu valley", Journal of Business and Social Sciences Research, 1(2), 215-233.

Puri, R. (1996), "Measuring and modifying consumer impulsiveness: a cost-benefit accessibility framework", Journal of Consumer Psychology, 5(2), 87-113.

Putra, A.H.P.K. et al. (2017), "Implication of external and internal factors of mall consumers in indonesia to impulsive buying behaviour", International Journal of Business Accounting and Management, 2(4), 1-10.

Ramanathan, S. \& G. Menon (2006), "Time-varying effects of chronic hedonic goals on impulsive behaviour", Journal of Marketing Research, 43(4), 628-641.

Roberts, J.A. \& E. Jones (2001), "Money attitudes, credit card use, and compulsive buying among american college students", Journal of Consumer Affairs, 35(2), 213-240.

Roberts, J.A. (1998), "Compulsive buying among college students: an investigation of its antedecents, consequences, and implications for public policy", Journal of Consumer Affairs, 32(2), 295-319.

Robinson, J.P. et al. (eds.) (1991), Criteria for scale selection and evaluation in measures of personality and social psychological attitudes, Academic Press.

Rook, D.W. \& M.P. Gardner (1993), "In the mood: impulse buying's affective antecedents", Research in Consumer Behaviour, 6(7), 1-28.

Rook, D.W. \& R.J. Fisher (1995), "Normative influences on impulsive buying behaviour", Journal of Consumer Research, 22(3), 305-313.

Rook, D.W. (1987), “The buying impulse”, Journal of Consumer Research, 14(2), 189-199.

Roy, S. \& C. Chakraborty (2021), "Panic buying situation during COVID-19 global pandemic", Journal of Information Technology Management, 13(2), 231-244.

Salari, N. et al. (2020), "Prevalence of stress, anxiety, depression among the general population during the COVID-19 pandemic: a systematic review and meta-analysis", Globalization and Health, 16(1), 1-11.

Scherhorn, G. et al. (1990), “Addictive Buying in West Germany: An Empirical Study”, Journal of Consumer Policy, 13(4), 355-387.

Schiffman, L. \& L. Kanuk (2010), Consumer behaviour, Prentice Hall.

Schiller, F. et al. (2021), "Stockpile purchasing in the emerging COVID-19 pandemic is related to obsessive-compulsiveness", Journal of Affective Disorders Reports, 4, 100116.

Schlosser, S. et al. (1994), "Compulsive Buying: Demography, Phenomenology, and Comorbidity In 46 Subjects", General Hospital Psychiatry, 16(3), 205-212.

Schmitt, B. (1999), "Experiential marketing”, Journal of Marketing Management, 15(1-3), 53-67.

Shahjehan, A. et al. (2012), "The effect of personality on impulsive and compulsive buying behaviours", African Journal of Business Management, 6(6), 2187-2194.

Shapiro, J.M. (1992), "Impulse buying: a new framework", Developments in Marketing Science, 15, 76-80.

Sharma, P. et al. (2010), "Impulse buying and variety seeking: a trait-correlates perspective", Journal of Business Research, 63(3), 276-283. 
Küçükkambak, S.E. \& M. Süler (2022), “The Mediating Role of Impulsive Buying in The Relationship Between Fear of COVID-19 and Compulsive Buying: A Research on Consumers in Turkey”, Sosyoekonomi, 30(51), 165-197.

Sharma, R. (2011), “An investigation into 1mpulse buying behaviour among indian urban adolescents", Abhigyan, 28(4), 43-50.

Shehzadi, K. et al. (2016), "Impact of personality traits on compulsive buying behaviour: mediating role of impulsive buying", Journal of Service Science and Management, 9(05), 416.

Sheth, J. (2020), "Impact of COVID-19 On Consumer Behaviour: Will The Old Habits Return or Die?”, Journal of Business Research, 117, 280-283.

Shoham, A. \& M.M. Brenčič (2003), "Compulsive buying behaviour”, Journal of Consumer Marketing, 20(2), 127-138.

Sneath, J.Z. et al. (2009), "Coping with a natural disaster: losses, emotions, and impulsive and compulsive buying", Marketing Letters, 20(1), 45-60.

Sofi, S.A. \& F.A. Nika (2016), “The Role of Personality in Impulse Buying Behaviour”, Jindal Journal of Business Research, 5(1), 26-50.

Sulaiman, E. et al. (2021), "Model antecedents, behaviour and consequences (abc) of social media information and compulsive panic buying relationship to buying decisions: a conceptual framework", International Journal of Ecma Science, 1(1), 1-7.

Sun, T. \& G. Wu (2011), "Trait predictors of online 1mpulsive buying tendency: a hierarchical approach", Journal of Marketing Theory and Practice, 19(3), 337-346.

Sun, T. et al. (2004), "Psychological antecedents of impulsive and compulsive buying: a hierarchical perspective", In The Proceedings of The Society For Consumer Psychology 2004 Winter Conference, 168-174.

Sun, T.R. \& R. Yazdanifard (2015), "The review of physical store factors that influence impulsive buying behaviour", International Journal of Management, Accounting and Economics, 2(9), 1048-1054.

Tabachnick, B.G. \& L.S. Fidell (2013), Using Multivariate Statistics, Sixth Edition, Pearson.

Taylor, S. et al. (2020), "Development and initial validation of the COVID stress scales", Journal of Anxiety Disorders, 72, 102232.

Terlep, S. (2020), "Why clorox wipes are still so hard to find; shortage isn't improving; 'within 3045 minutes they're gone", Wall Street Journal, May 7.

Torlak, Ö. \& M.A. Tiltay (2010), “Anlık satın alma ölçeklerinin türk tüketicisi için uyarlanmasına yönelik bir deneme”, Ulusal Pazarlama Kongresi, İzmir, 406-422.

Troisi, J.D. et al. (2006), "Materialism and money spending disposition as predictors of economic and personality variables", North American Journal of Psychology, 8(3), 421-436.

Valence, G. et al. (1988), “Compulsive buying: concept and measurement”, Journal of Consumer Policy, 11(4), 419-433.

Verplanken, B. \& A. Herabadi (2001), "Individual differences in impulse buying tendency: Feeling and no thinking", European Journal of Personality, 15(1), 71-83.

Verplanken, B. \& A. Sato (2011), "The Psychology of Impulse Buying: An Integrative SelfRegulation Approach”, Journal of Consumer Policy, 34(2), 197-210.

Vishnu, P. \& A.R. Raheem (2013), "Factors influencing impulse buying behaviour", European Journal of Scientific Research, 100(3), 67-79. 
Wang, C.C. \& H.W. Yang (2008), "Passion For Online Shopping: The Influence of Personality and Compulsive Buying", Social Behaviour and Personality: An International Journal, 36(5), 693-706.

Watanabe, T. \& Y. Omori (2020), "Online Consumption During The COVID-19 Crisis: Evidence From Japan”, COVID Economics, 38(16), 218-252.

Weinberg, P. \& W. Gottwald (1982), "Impulsive consumer buying as a result of emotions", Journal of Business Research, 10(1), 43-57.

West, C.J. (1951), "Results of two years' of study into impulse buying”, Journal of Marketing (pre1986), 15(3), 362.

Weun, S. et al. (1997), “A Parsimonious Scale To Measure Impulse Buying Tendency”, In Ama Educators' Proceedings, 8, 8-26.

Winestine, M.C. (1985), "Compulsive Shopping As A Derivative of A Childhood Deduction”, The Psychoanalytic Quarterly, 54(1), 70-72.

Xiao, H. et al. (2020), “A Diary Study of Impulsive Buying During The COVID-19 Pandemic”, Current Psychology, 1-13.

$\mathrm{Xu}, \mathrm{Y}$. (2008), "The influence of public self-consciousness and materialism on young consumers' compulsive buying”, Young Consumers, 9(1), 37-48.

Yang, D.J. et al. (2011), "A study of the factors that affect the impulsive cosmetics buying of female consumers in kaohsiung", International Journal of Business and Social Science, 2(24), 275-282.

Youn, S. \& R.J. Faber (2000), “Impulse buying: its relation to personality traits and cues”, Advances in Consumer Research, 27, 179-185.

Yurchisin, J. \& K.K. Johnson (2004), "Compulsive buying behaviour and its relationship to perceived social status associated with buying, materialism, self-esteem, and apparelproduct involvement", Family and Consumer Sciences Research Journal, 32(3), 291314.

Zhang, Y. \& L.J. Shrum (2009), "The influence of self-construal on impulsive consumption”, Journal of Consumer Research, 35(5), 838-850. 
Küçükkambak, S.E. \& M. Süler (2022), "The Mediating Role of Impulsive Buying in The Relationship Between Fear of COVID-19 and Compulsive Buying: A Research on Consumers in Turkey”, Sosyoekonomi, 30(51), 165-197. 